\title{
Monoclonal Antibodies
}

\section{MAb 6D5 Against Proteins Overexpressed in Hepatocellular Carcinoma Cell Lines}

\begin{abstract}
ANTIGEN USED FOR IMMUNIZATION
Apoptotic cells of human hepatocellular carcinoma (HCC) cell line HUH7 were used for immunization. Apoptosis was induced by ultraviolet-C (UVC) irradiation.
\end{abstract}

\section{METHOD OF IMMUNIZATION}

UVC treated apoptotic HUH7 cells were injected into peritoneal cavity of 6- to 8-week-old female BALB/c mice at 3-week intervals. The mice received three booster injections. No adjuvant was used. Immunity was assessed by cell-ELISA. Fusion was performed 3 days after the last booster.

\section{PARENTAL CELL LINE USED FOR FUSION}

Sp2/0 mouse myeloma cell line

\section{SELECTION AND CLONING PROCEDURE}

Fused cells were plated into 96-well tissue culture plates in hybridoma growth medium consisting of high-glucose DMEM supplemented with $20 \%$ FCS, 100 IU penicillin, $100 \mu \mathrm{g}$ streptomycin, non-essential amino acids, and hybridoma selection reagents (hypoxantine, aminopterin, thymidine [HAT]; Sigma, St. Louis, MO). Screening of hybrid cells was performed by cell-ELISA and clones with high absorbance values were subjected to subclonings by limited dilution.

\section{HEAVY AND LIGHT CHAINS OF IMMUNOGLOBULIN}

IgG3, $\kappa$ chain

\section{SPECIFICITY}

We analyzed 15 HCC cell lines by Western blotting. Two ma- jor proteins with molecular weights close to $80 \mathrm{kDa}$ were found to be expressed either alone or concomitantly in all studied cells, except FLC4, which resembles normal hepatocytes. ${ }^{(1)}$ A third protein band with the lowest molecular weight was observed only in Hep3B cells. The antibody is also suitable for the detection of its target proteins both in immunofluorescence and in immunohistochemistry. 6D5 MAb works well in frozen and paraffin-embedded human tissues.

\section{SPECIFIC ANTIGEN IDENTIFIED}

Specific antigen not determined

\section{AVAILABILITY}

Tissue culture supernatant

Ascitic fluid

Hybridoma cells

$\begin{array}{ll}\text { Yes } \checkmark & \text { No } \\ \text { Yes } \checkmark & \text { No } \\ \text { Yes } & \text { No } \checkmark\end{array}$

\section{ADDRESS CORRESPONDENCE TO:}

Tamer Yagci

Bilkent University

Department of Molecular Biology and Genetics

Science Building B

06800 Bilkent-Ankara

Turkey

Telephone: +90-312-2902402

Fax: +90-312-2665097

E-mail: tyagci@fen.bilkent.edu.tr

\section{REFERENCES}

1. Arad U, Axelrod J, Ben-nun-Shaul O, Oppenheim A, and Galun E: Hepatitis B virus enhances transduction of human hepatocytes by SV40-based vectors. J Hepatol 2004; 40(3):520-526. 